\title{
KIPRAH KYAI HASYIM ASYARI DALAM DISKURSUR HADITS DI INDONESIA
}

\author{
Mu'min \\ Mahasiswa Pascasarjana Uin Sunan Gunung Djati Bandung \\ J1. A.H Nasution no. 105 Bandung 40614 tlp. 081221901125 \\ E-Mail: muminwelah@gmail.com
}

\begin{abstract}
Abstrak
Tulisan ini ingin menjelaskan bagaimana pemikiran kyai Hasyim Asyari tengtang hadis, sebagai ulama yang banyak menimba ilmu dari berbagai pesantren di tanah jawa dan diakhiri dan di makkah. Dengan menggunakan studi pustaka pada karya-karya kyai Hasyim Asyari kemudian menganalisis arah dan peta pemikirannya ditemukan bahwasanya Kyai Hasyim Asyari mempunyai perhatian lebih terhadap hadis, meskipun kyai Hasyim Asyari tidak menysun satu buku khusus mengenai pembahasan tengtang hadis atau ilmu hadis, namun dalam beberapa karyanya terkadang lebih dominan mengunakan hadis sebagai dalil untuk memecahkan satu kasus tertentu. Perlu penelitian lebih mendalam bagaimana methodologi yang di gunakan kyai Hasyim 'Asyari dalam menyusun setiap karyanya yang lebih dominan mengunakan hadis.
\end{abstract}

Kata Kunci: Hadis, Hasyim Asyari, Sanad

\section{A. Pendahuluan}

Kyai Hasyim Asya'ri merupakan ulama dipenghujung abad ke 19 dan awal abad ke $20 \mathrm{~m}$ yang mempunyai peranan penting bagi kemerdekaan dan pembangunan masyarakat di Indonesia yang ketika itu pulau jawa khususnya, sudah berabad-abad menjadi bagian dari tanah kolonialisme, yang terpuruk pendidikan dan terendahkan martabatnya. Kolonialisme sudah merendahkan martabat bangsa yang menganggap bahwa bangsa nusantara tidak mempunyai peradan tulis menulis, pada waktu itu nusantara sudah mengenal bahasa arab sebagai alat surat menyurat.

Kyai Hasyim Asya'ri tampil sebagai politisi sekaligus ulama yang mengayomi masyarakat, baik dalam tataran ukhrawi dan duniawi, ditengah-tengah tantangan dan tekanan pemerintah kolonialisme yang pada saat itu selalu memantau pergerakan para ulama.

Ditengah-tengah tekanan dan desakan pemerintah kolonialislah, para ulama terserap tenaganya untuk melawan pemerintah kolonial sehingga ulama nusantara pada waktu itu jarang sekali yang membuat karya tulis untuk bahan pengajaran ataupun untuk bacaan umum, padahal perbandingannya sebelum abad 19 dan 20 sudah banyak ulama yang sudah menulis karya berupa sebuah kitab dan berbahasa arab seperti yaitu tanqih al-qawl al-hathith bi sharh lubab al-hadith $(1277 \mathrm{H} / 1861 \mathrm{M}) .{ }^{1}$ dan bahakan para ulama terdaulu sangat memahami ilmu falaq.

Beberapa ulama yang mempunyai perhatian pada tafsir dan hadis pada abad 20, hanya beberapa orang saja, tercatat dalam sejarah ulama yang mempunyai peranan dalam penulisan tafsir dan komentar pada beberapa kitab hadis. Seperti halnya Yassin Padani, Syaikh Mahfudz Al-Tarmasi, Syaikh An-Nawawi Al-Bantani, A. Hassan, Ahmad Surkati.

Hasyim Asyari merupakan salah satu ulama yang sangat produktif, terbukti dari beberapa karya yang ditulisnya, yang menulis hampir dari berbagai disiplin ilmu seperti ilmu tasawuf, fiqh, hadis dan beberapa kitab yang membahas ahlaq.

Pengkajian pada karya kiyai hasyim asya ri dalam disiplin ilmu hadis, sebenarnya sudah dilakukan oleh afriadi dalam

\footnotetext{
1 Muhammad Mustaqim Mohd zarif, Penulisan Karya Hadis Nusantara Abad Ke-19: Antara Syeikh Nawawi Banten Dan Syeikh Wan Ali Kutan AlKalantan, Sunnah Nabi: Realiti dan cabaran semasa, 2011358
} 
journalnya yaitu pemikiran hadis $k h$. M. Hasyim asy'ari dan kontribusinya terhadap kajian hadis di Indonesia yang pembahasannya lebih menekankan pada bagaimana kyai Hasyim Asya'ri mengomentari hadis. Sedangkan penulis akan meneliti bagaimana methodologi Hasyim Asyari dalam menjelaskan hadis dan bagaimana sikap Hasyim Asyari ketika mengelompokan hadis dilihat dari qualitasnya.

\section{B. PEMBAHASAN}

\section{Biografi}

Nama lengkap kyai Hasyim Asyari adalah M. Muhammad Bin Ashari Bin Abdul Wahid Bin Abdul Halim atau yang populer dengan pangeran benawa bin abdurahman yang dikenal dengan jaka tingkir (sultan hadiwijaya ) bin abdullah bin abdul aziz bin fatah bin maulana ishak bin ainul yaqin, atau lebih dikenal dengan sebutan sunan giri. Sementara dari garis ibu halimah binti layinah binti sihah nin abdul jabar bin ahmad bin pangeran sambo dan pangeran benawa bin jaka tingkir (Prabu Brawijaya), ia dilahirkan dari keluarga ulama berpengaruh kyai jawa pada hari selasa kliwon tanggal 14 februari $1871 \mathrm{M} / 12$ dzulqa'idah $1287 \mathrm{H}$ di Desa Gedang daerah Jombang dan wafat pada tanggal 25 Juli 1947 M. Bertepatan dengan 7 Ramadhan $1366 \mathrm{H}^{2}$.

Hasyim Asya'ri kecil lebih banyak menghabiskan masa hidupnya dipesantren, dengan umur yang relatif muda sudah berkelana keberbagai pesantren ternama di Indonesia hingga akhirnya ke mekkah. Dalam rihlah ilmiahnya inilah kyai Hasyim Asya'ri mendapatkan berbagai ilmu hingga akhirnya mendapatkan riwayat dari Mahfuzh Al-Tarmasi

Pada usia 21 tahun menikahi Nafisah yaitu putri Kyai Ya'qub (Sidoarjo), bertepatan dengan tahun $1892 \mathrm{M} / 1308 \mathrm{H}$. Setelah pernikahan-Nya kyai Hasyim Asyari bersama istri dan mertuanya berangkat ke mekah untuk menunaikan ibadah haji. Selanjutnya tinggal dimekah untuk menuntut

\footnotetext{
2 Lathiful Khuluq, Pajar kebanguna Ulama Yogyakarta: LkiS, 2008. 26-30
}

ilmu. Tetapi tujuh bulan kemudian, nafisah meninggal dunia setelah melahirkan seorang putera bernama Abdullah dan setelah empat puluh hari kemudian putera Hasyim Asyari meninggal dunia.

keduanya dengan puteri kiyai Romli dari desa karangkates (Kediri) yang bernama khadijah bertepatan tahun $1899 \mathrm{M} / 1315 \mathrm{H}$, pernikahan keduapun tidak begitu lama karena dua tahun kemudain khadijah meninggal dunia.

Pernikahan ketiga yaitu dengan nafiqah anak Kyai Ilyas (Madiun). Dari hasil pernikahan-Nya mempunyai sepuluh orang anak, yaitu: Hannah, Khoiriyah, Aisyah, Azizah, Abdul Wahid, Abdul Hakim, Abdul Karim Ubaidillah, Mashuroh, dan Muhammad Yusuf, pernikahan yang ketigapun kandas di tenagh jalan karena Nafiqah meninggal pada tahun $1920 \mathrm{M}$.

Pernikahan ke empat yaitu dengan menikah lagi dengan masruroh putri kyai hasan yang juga pengasuh pesantren kapurejo (kediri).dari hasil perkawinannya kyai hasim asyari memiliki 4 anak yaitu: Abdul Qadir, Fatimmah, Khadijah, dan Muhammad Ya'qub.

\section{Pendidikan}

Hasyim Asyari sudah sejak kecil menuntut ilmu, sehingga dalam umur 15 tahun sudah layak untuk berpindah-pindah pesantren guna memperdalam ilmu agama, karena pada saat itu santri yang sudah mapan ilmunya dari satu pesantren maka dianjurkan untuk pindah pesantren guna memperdalam berbagai disiplin ilmu yang lain.

Pesantren pertama di tempuh di pesantren orang tauanya yaitu terhitung dari semenjak kanak-kanak samai berumur 15 an, sedangkan pesantren yang kedua dan seterusnya yang tercatat sebagai pendalaman dari berbagai disiplin yaitu pesantren probolinggo, pesantren langitan (Tuban, sampai Trenggelis Semarang, Pesantren Kedemangan, Pesantren Bangkalan (kyai kholil), Pesantren Siwalan Panji (Sidoarjo) yang diasuh oleh Kyai Ya'qub.

Setelah belajar ditanah air merasa sudah cukup akhirnya kyai Hasyim Asya'ri berguru ketanah Hijaj dan berguru kepada Syekh Ahmad Amin Al-Attar, Sayyid Sultan bin 
Hashim, Sayyid Ahmad Bin Hassan AlAttas, Syekh Said Al-Yamani, Sayyid 'Alawibin Ahmad Al-Saqqaf, Sayyid Abbas Maliki, Sayyid Abdullah Al-Zawawi, Syekh Salih Bafadal, dan Syekh Sultan Hashim Dagastani, Syekh Shuayb bin Abd AlRahman, Syekh Ibrahim Arab, Syekh Ramatullah, Sayyid Alwi Al-Saqqap, Sayyid Abu Bakr Shata Al-Dimyati dan Sayyid Husyayn Al-Habshi dan tidak Kalah Penting Kyai Hasyim Asya'ri berguru kepada ulama Indonesia yang sudah menetap di makkah diantaranya yaitu Syekh Ahmad Khatib Minangkabawi, Syekh Nawawi Al-Bantani, dan Syekh Mahfuz Al-Tarmisi ${ }^{3}$.

\section{Karya-karya kyai Hasyim Asya'ri}

Kyai Hasyim Asyari merupakan ulama yang sangat produktif sehingga selama hidupnya sudah menghasilkan banyak karya, yang terdiri dari berbagai disiplin ilmu :

1. At-tibyan fi al-nahy 'an muqatha'at al-arham wa al-aqarib wa al-ikhwan. Kitab ini selesai ditulis pada senin, 20 syawal 1260 $\mathrm{h}$ dan diterbitkan oleh muktabah al-turats alIslami, pesantren tebuireng. Berisikan pentingnya membangun persaudaraan di tengah perbedaan serta bahaya memutus tali persaudaraan

2. Muqaddimah Al-Qanun Al-Asasi Li Jam'iyyat Nahdlatul Ulama.Dari kitab ini para pembaca akan mendapat gambaran bagaimana pemikiran dasar beliau tentang NU. Di dalamnya terdapat ayat dan hadis serta pesan penting yang menjadi landasan awal pendirian Jam'iyah NU. kitab ini bisa disebut sebgai "bacaan wajib" bagi para pegiat NU.

3. Risalah Fi Ta'kid Al-Akhdzi Bi Mazhab Al-A'immah Al-Arba'ah. Mengikuti manhaj para imam empat yakni Imam Syafi'i, Imam Malik, Imam Abu Hanifah dan Imam Ahmad Bin Hanbal tentunya memiliki makna khusus. Mengapa akhirnya mengikuti jejak pendapat imam empat tersebut? Temukan jawabannya di kitab ini.

\footnotetext{
3 Lathiful Khuluq, Pajar Kebangunan Ulama. Yogyakarta: LkiS, 2008. 26-30.
}

4. Arba'ina hadisan tata'allaqu bi mabadi' jam'iyyat nahdlatul ulama. Hidup ini tak akan lepas dari rintangan dan tantangan. Hanya pribadi yang tangguh serta memiliki sosok yang kukuh dalam memegang prinsiplah yang akan lulus sebagai pememang. Kitab ini berisikan 40 hadis pilihan yang seharusnya menjadi pedoman bagi warga nu.

5. Adab al-'alim wa al-muta 'allim, yaitu kitab yang berisi tentang akhlak guru dan murid

6. Risalah Ahl Al-Sunnah Wa AlJama'ah Fi Hadith Al Mawta Wa Ashrat AlSa'ah Wa Bayan Mafhum Al-Sunnah Wa AlBid'ah, (Risalah Ahlus Sunnah Wal Jama'ah: mengenai hadis-hadis tentang kematian dan tanda-tanda hari kiamat serta penjelasan mengenai sunnah dan bid'ah)

7. Ziyadah Al-Ta'Liqat 'Ala Manzumat Al-Shaikh 'Abd Allah Ibn Yasin AlFasuruani. Catatan tambahan mengenai syair Syaikh'Abdullah bin Yasin pasuruan, berisi bantahan hasyim asy'ari terhadap kritikan Syaikh 'Abdullah bin Yasin pasuruan terhadap nahdlatul ulama

8. Al-Tanbihat Al-Wajibah, berisi nasihat penting bagi orang yang merayakan kelahiran Nabi Muhammad.

9. Al-Risalah Fi Al-Aqa'id, (Risalah tentang keimanan)

10. Al-Hadith Al-Mawt Wa Ashrah Al-Sa'ah. Hadis mengenai kematian dan

kiama

11. Al-nur al-mubin fi mahabbati sayyid al-mursalin. Biografi dan akhlak baginda Nabi muhammad saw ada di kitab ini. Kiai hasyim juga menyarankan agar umat Islam senantiasa mencintai baginda nabi dengan mengirimkan shalawat dan tentu saja mengikuti ajarannya.

\section{Sanad periwayatan}

Sebagai ulama yang sangat penomenal, kyai Hasyim Asyari memang mempunyai wawasan yang luas, salah satunya 
penguasaan pada bidang ilmu hadist, tetapi dalam hidupnya kyai Hasyim Asyari tidak membuat buku yang langsung membahas ilmu ulumul hadis atau matan hadis secara langsung tapi lebih pada pemaparan pemahaman beliau dari cabang ilmu tersebut yang akhirnya di tuangkan pada buku-buku yang berbentuk risalah yang penyajiannya sederhana.

Hasil rihlah ilmiahnya di makkah memang membuahkan hasil, sehingga pada massa hidupnya kyai Hasyim Asyari dianggap sebagai ulama ahli hadis di tanah air, sampai-sampai gurunya sendiri (kyai. Khalil bangkalan) ingin berguru kepadanya. ${ }^{4}$

Kyai Hasyim Asyari mempunyai jalur sanad dari syeikh mahfudz al-tarmisi yaitu ketika menuntut ilmu di makkah. ${ }^{5}$ ketika itu kyai hayim asyari mendapat ijazah untuk mengajar shahih bukhary.

Sebagai orang yang selalu haus akan ilmu, di makkah pun kyai Hasyim Asyari tidak hanya berguru kepada syeikh mahfudz al-tarmisi melainkan bergguru kepada syeikh yang termashur pada waktu itu di makkah seperti syaikh 'abd al-hamîd al-durustâni, syaikhmuhammad syu'ayb almaghrîbi,syaikh sata dan syaikh dagistani. Nama-nama tersebut merupakan ulama yang terkenal pada masa itu. Hanya saja tidak ada sumber tertulisyang menjelaskan tentang bidang apa yang kh. Hasyim asy`ari pelajari dari ulama-ulama terkenal tersebut ${ }^{6}$

\section{Kitab Risalah Ahl Al-Sunnah Wa Al-Jama'ah Fi Hadith Al-Mawta Wa Ashrat Al-Sa'ah Wa Bayan Mafhum Al- Sunnah Wa Al-Bid'ah.}

a. Latar Belakang Penulisan

\footnotetext{
${ }^{4}$ Supriyanto, Konsep Etika KYAI. Hasyim Asy'ari dalam Budaya Mendidik, JURNAL PEMIKIRAN ALTERNATIF KEPENDIDIKAN INSANIA/Vol. 14|No. 3|Sep-Des 2009|512-521

Nuriah Miftahul Jannah, Studi Komparasi Pemikiran Kh. Hasyim Asy'ari Dan Hamka Tentang Pendidikan Karakter, Jakarta: Jurusan Pendidikan Agama Islam Fakultas Ilmu Tarbiyah Dan Keguruan Uin Syarif Hidayatullah, 2016. 49

${ }^{6}$ Ahmad Khoirul Fata, Kontekstualisasi Pemikiran Kh. Hasyim Asy`Ari

Tentang Persatuan Umat Islam, Miqot Vol. XXXVIII No. 2 Juli-Desember 2014, 325
}

Penulisan risalah ahl al-sunnah wa al jama'ah tidak bisa dilepaskan dari pengaruh pembaharuan pada masa periosde ini, karena penulisan inipun merupakan respon dari maraknya paham keagagamaan yang muncul ketika itu. H seperti paham abduh dan gerakan paham Abdullah bin Abdul Wahab. Penulisan kitab ini juga dimaksudakan untuk mengkanter berbagai pemikiran yang baru serta mengeliminer berbagai pahamyang tidak cocok dengan budaya setempat.

\section{b. Sistematika dan metode penulisan}

Dalam penyusunan kitab hadis, dikenal ada empat macam sistematika, yaitu: pertama, sistematika sahih dan sunan, yaitu kitab hadis yang disusun berdasarkan kitabkitab tertentu, setiap kitab terdiri dari beberapa bab,sistematika ini juga dikenal dengan istilah sistematika fiqhiyah. Misalnya ditulis dalam kitab-kitab taharah, salat dan sebagainya, setiap kitab-kitab tersebut terdiri dari beberapa bab. Kedua, sistematika musnad, yaitu kitab hadis yang ditulis berdasarkan nama periwayat pertama yang menerima dari nabi. Ketiga, sistematika kamus, yaitu kitab hadis yang ditulis berdasarkan huruf abjad hijaiyah.Keempat, kitab hadis yang disusun berdasarkan lima bagian-bagian tertentu seperti perintah, larangan, kabar, ibadah dan af'al secara umum. $^{7}$

Adapun pada tulisan ini menggunakan metode syarah, yaitu mengutip suatu hadis kemudian menjelaskannya secara panjang lebar. Lebih rinci,atau hanya menjelaskan secara sederhana saja. Dalam metode ini biasanya pengarang akan menempuh langkah-langkah sebagai berikut: pertama, mengutip hadis dengan menyebutkan rawi pertama dan mukharrij-nya. Kedua, mengutip hadis dengan menuliskan matannya saja. Ketiga, mengutip hadis dengan menyebutkan perawi pertama saja

\footnotetext{
Afriadi putra. Pemikiran hadis kh. M. Hasyim asy'ari dan kontribusinya terhadap kajian hadis di indonesia, Wawasan: Jurnal Ilmiah Agama dan Sosial Budaya, 2016, 6
} 
Dalam kitab ini memiliki 10 pasal, dan hadis yang terumuat dalam kitab ini yaitu sekitar 62 hadis, dari sepuluh bab yaitu :

1. Penjelasan sunnah dan bid'ah terdapat 2 hadis, dalam pasal ini dijelaskan panjang lebar mengenai bidah dan macamnya, pendapat yang dikutif merupakan pendapat syaikh zaruq dalam kitab udatul murid. $^{8}$

2. Masyarakat Jawa dan Ahl Sunnah Wa Al-Jama'ah, awal muncul dan penyebaran bid'ah di jawa, macam-macam bentuk bid'ah yang ada sekarang terhadap oramg hadis terdapat 1penjelasan ulama salah tentang al-asawewad al-a'zam (golongan paling besar), serta pentingnya berpegang terhadap imam yang empatpenjelasan tentang kebolehan taqlid bagi orang yang tidak mampu berijtihad.terdapat satu hadis. Dalam pasal dua pendapat ulama yang dikutip yaitu, pendapatnya Al-Alamah Mula Ali Qari, Qadli Iyad.

3. Penjelasan ulama salaf tentang alaswad al-a'zam (golongan paling besar), serta pentingnya berpegang terhadap imam yang empat.terdapat 4 hadis, dalam pasal ini nampaknya tidak mengutif dari pendapat yang lain, melaikan hanya uraian yang diuraikan dengan penejlasan hadis dengan hadis.

4. Penjelasan tentang kebolehan taqlid bagi orang yang tidak mampu berijtihad, dalam bab ini tidak ditemukan hadis penguat dalam menjelaskan maksud tema babnya. Yang menjadi dalil dalam pasal ini yaitu Q.S an-nahl 43 maka bertanyalah kepada orang yang memiliki pengetahuan jika kalian tidak mengetahui.

5. Urgensi kehati-hatian dalam berpedoman terhadap agama dan ilmu terdapat lima hadis. Dalm pasal ini hanya almunawi yang dikutif, selebihnya merupakan

8 Hasyim Asyari, Risalah Ahl Sunnah, Jakarta: LTM PBNU dan Pesantren Ciganjur, 2011. uraian hadis dengan hadis. Penjelasan hadis tentang tanda-tanda hari kiamat dan hilangnya ilmu dan menjamurnya kebodohan, terdapat 9 hadis

6. Penjelasan hadis tengtang tanda-tanda hari kiamat dan hilangnnya ilmu dan menjamurnya kebodohan. Dalam pasal ini tidak terdapat nukilan dari ulama yang lain, hampir seluruhnya berupa penjelasanpenjelasan hadis dengan hadis.

7. Balasan bagi orang-orang yang mengajak kepada kesesatan dan contoh yang buruk, terdapat lima hadis. Berupa penjelasan-penjelasan hadis dengan hadis

8. Penjelasan hadis tentang firqah, terdapat 2 hadis, dalam pasal ini kyai Hasyim Asyari menukil pendapat Syihab Alkhafaji, Abi Jamrah, Abu Mansur bin Thahir Al-Tamimi dan Ibnu Ruslan

9. Penjelasan tengtang tanda-tanda datangnya hari kiamat, terdapat 33 hadis. Terdapat 4 hadis.pada pasal ini kyai Hasyim Asya'ri mengambil pendapat imam nawawi dan ibnu hajar dari syarah Fath al-Bari

10. Penjelasan tengtang kematian dan alam sesudahnya. Berupa uaian penjelasan hadit dengan dikuatkan oleh Alquran dan dan penjelasan-penjelasan ulama.

Dari jumlah hadis yang dihitung oleh afriadi putra, yaitu sekitar 62 hadis, merupakan hadis yang tersebar diberbagai kitab hadis, tidak terbatas oleh kutub tis'ah saja. Yang menunjukan bahwasanya kyai Hasyim Asya'ri memiliki pengetahuan hadis dari berbagai literatur, walaupun dalam menejelaskan hadis tidak menerangkan status kualitas hadis dan kuantitas hadis.

\section{KeSIMPULAN}

Kyai Hasyim Asya'ri merupakan ulama yang sangat produktif pada masanya, yaitu pada awal abad 20 M. Yang banyak menghasilkan karya tulis dari berbagai disiplin ilmu. 
Kyai Hasyim Asya'ri tidak saja dikenal sebagai ulama tetapi dikenal juga sebagai pahlawan Nasional, karena kontribusinya pada perjuangan kemerdekaan Indonesia

Kyai Hasyim Asya'ri memiliki berbagai pengetahuan dan kedalaman memahami ajaran Islam, serta dikenal sebagai kyai yang mempunyai sanad hadis dari Mahfuz AlTarmisi.

Dalam karya tulisnya, Kyai Hasyim Asyari tidak banyak menjelaskan hadis dari sudut pandang Ilmu Hadits, baik Ilmu Hadits diroyah maupun riwayah.

\section{Daftar Pustaka}

Asya'ri, Hasyim. Risalah ahlul sunnah wal jamaah. Diterjemahkan oleh oleh Ngabdurahmaan al-Jawi. Jakarta: 1tm PBNU dan Pesantren Ciganjur, 2011.

Fata, Ahmad khoirul. kontekstualisasi pemikiran kh. Hasyim asy`ari Tentang Persatuan Umat Islam. Miqot vol. Xxxviii no. 2 Juli-Desember 2014

Jannah, Nuriah Miftahul. Studi Komparasi Pemikiran KH. Hasyim Asy'ari dan Hamka Tentang Pendidikan Karakter, Jakarta: Jurusan Pendidikan Agama Islam Fakultas Ilmu Tarbiyah dan Keguruan UIN Syarif Hidayatullah, 2016
Mas'ud, Abdurrahman. Intelektual Pesantren: Perhelatan Agama Dan Tradisi. Yogyakarta:LKiS, 2004

khuluq, Lathiful. Fajar kebangunan ulama. Yogyakarta: LKiS, 2008.

Putra, afriadi. "Pemikiran Hadis KH. M. Hasyim asy'ari dan kontribusinya terhadap kajian hadis di Indonesia." Wawasan: Jurnal Ilmiah Agama dan Sosial Budaya 1 (January 2016): 6.

Supriyanto, Konsep Etika Kyai. Hasyim asy'ari dalam budaya mendidik, Jurnal pemikiran Alternatif kependidikan Insania|vol. 14|no. 3|sep-des 2009

Zarif, Muhammad Mustaqim Mohd. "Penulisan Karya Hadis Nusantara Abad Ke-19: Antara Syeikh Nawawi Banten dan Syeikh Wan Ali Kutan AlKalantani." Edited By Fauzi Derahman. Sunnah Nabi: Realiti Dan Cabaran Semasa (Jabatan Al-Quran dan alhadith), 2011: 358. 